protect against toxicity are bypassed doubt has been expressed about its safety in the elderly. ${ }^{10}$ Our study, however, shows that in the dose needed to heal subclinical osteomalacia $(0.5 \mu \mathrm{g}$ daily) ${ }^{7}$ alfacalcidol proved free from the risk of hypercalcaemia. Although there were four episodes of hypercalcaemia, the circumstances under which this occurred suggested that it was not due to vitamin $\mathrm{D}$ intoxication. Moreover, none of the episodes was accompanied by a deterioration in renal function. In this type of study it is very difficult to separate the effects of treatment on renal function from those of unrelated systemic disease. In the few instances of an increase in serum creatinine concentration this appeared to be due to progression of the underlying illness which had precipitated the patients' original hospital admission rather than to a side effect of treatment. ${ }^{11}$

Experience with renal osteodystrophy has shown that although hypercalcaemia may appear in the early stages of treatment, it may also develop for the first time when the osteomalacia has almost healed. ${ }^{12}{ }^{13}$ This is a reflection of skeletal uptake of calcium as osteoid remineralises which offsets any tendency of calcium absorption, stimulated by treatment, to cause hypercalcaemia. This buffering capacity, however, is progressively lost as the bone disease heals. Hence there was some anxiety that the small excess of osteoid in the elderly patients in this series would be insufficient to protect them against hypercalcaemia. Fortunately, it is clear that the posttreatment serum calcium concentration is not critically dependent on the presence or extent of trabecular osteoid. The safety of the present regimen is probably a function of dose, since patients with hypoparathyroidism ${ }^{14}$ or osteoporosis ${ }^{15}$ (who also do not have an excess of osteoid) may become hypercalcaemic when treated with larger doses of alfacalcidol or calcitriol.

GAC was supported by the research committee of the Trent Regional Health Authority.

\section{References}

1 Anderson I, Campbell AER, Dunn A, Runciman JBM. Osteomalacia in elderly women. Scott Med f 1966;2:429-35.

Chalmers J, Conacher WDH, Gardner DL, Scott PJ. Osteomalacia: a common disease

. long stay geriatric patients. Lancet 1975 ; $\mathrm{i}$ : 1404-6.

long stay geriatric patients. Lancet $1975 ; 1: 1404-6$. in the elderly? Lancet (in press).

5 Exton-Smith AN. Nutrition of the elderly. Br f Hosp Med 1971;5:639-46.

6 Aaron JE, Gallagher JC, Anderson J, et al. Frequency of osteomalacia and osteoporosis in fracture of the proximal femur. Lancet $1974 ; \mathrm{i}: 229-33$.

7 Hosking DJ, Campbell GA, Kemm JR, et al. Screening for subclinical osteomalacia in the elderly-normal ranges or pragmatism? Lancet 1983 ;ii: $1290-2$

$8 \mathrm{Kemm}$ JR, Campbell GA, Cotton RE, Hosking DJ, Boyd RV. Osteoid in bones of elderly patients without bone disease. Age Ageing 1984;13:144-51.

9 De Luca HF. Vitamin D. Metabolism and function. Berlin: Springer Verlag, 1979. 10 Parfitt AM. Screening for vitamin D depletion. Lancet $1984 ; \mathrm{i}: 227-8$.

Massry SG, Goldstein DA. Is calcitriol $\left(1,25(\mathrm{OH})_{2} \mathrm{D}_{3}\right)$ harmful to renal function ? 3AMA $1979 ; 242: 1875-6$

(In Lawson DEM, ed. Vitamin D. London: Academic Press, 1978:303-86.

作 作 $\mathrm{D}_{3}$ and 1,25 dihydroxy vitamin $\mathrm{D}_{3}$ on calcium and phosphorus metabolism in hypoparathyroidism. Metabolism 1975;24:1403-13.

15 Sorensen OH, Andersen RB, Christensen MS, et al. Treatment of senile osteoporosis with $1 \alpha$-hydroxy-vitamin $\mathrm{D}_{3}$. Clin Endocrinol (Oxf) 1977;7 (suppl):169-75s.

(Accepted 27 fune 1984)

\title{
Effect of an oral serotonin antagonist, ketanserin, on plasma ACTH concentrations in Nelson's syndrome
}

\author{
R W G PRESCOTT, W A RATCLIFFE, P KENDALL TAYLOR
}

\begin{abstract}
A study was performed to see whether ketanserin, a serotonin antagonist, would reduce the raised concentrations of adrenocorticotrophic hormone (ACTH) in patients with Nelson's syndrome. Six patients who had undergone bilateral adrenalectomy for Cushing's disease and who had Nelson's syndrome were given ketanserin $40 \mathrm{mg}$ twice daily and placebo, for at least two months each, in a double blind crossover study. Ketanserin had no effect on ACTH concentrations.

In healthy people serotonin seems to have a stimulatory role in the regulation of ACTH secretion, and the effect of ketanserin in reducing the ACTH response to hypoglycaemia suggested that it might prove useful in Nelson's syndrome. These results show that it is not indicated in these patients.
\end{abstract}

\footnotetext{
Department of Medicine (Geriatrics), Newcastle General Hospital, Newcastle upon Tyne

$\mathrm{R}$ W G PRESCOTT, $M D, M R C P$, first assistant in medicine (geriatrics)

Department of Chemical Pathology, Hope Hospital, Salford W A RATCLIFFE, BSC, PHD, senior biochemist

Department of Medicine, Royal Victoria Infirmary, Newcastle upon Tyne

P KENDALL TAYLOR, MD, FRCP, reader in endocrinology

Correspondence to: Dr P Kendall Taylor.
}

\section{Introduction}

Nelson's syndrome, characterised by increased skin pigmentation and high circulating adrenocorticotrophic hormone (ACTH) concentrations, results from the development of an ACTH secreting pituitary adenoma after bilateral adrenalectomy for Cushing's disease. Once it has developed the adenoma can be locally invasive and difficult to control by either irradiation or hypophysectomy. Hence there is a need for effective drug treatment, and drugs which may alter the neurotransmitter control of ACTH have been tried in this condition. ${ }^{12}$ Serotonin influences the release of corticotrophin releasing factor, and the relatively weak and non-specific antiserotonin agent cyproheptadine is sometimes useful in Cushing's disease or Nelson's syndrome. ${ }^{2}$ Ketanserin is a new and specific serotonin antagonist, and the present double blind study was therefore designed to evaluate its effect on the ACTH concentrations of patients with Nelson's syndrome.

\section{Patients and methods}

Five women and one man aged 36-65 years were studied. All had undergone bilateral adrenalectomy for Cushing's disease five to 23 years previously. The pituitary fossa was enlarged in two patients. Three patients had received external irradiation to the pituitary six to 17 years previously. Characteristic increased pigmentation was present in five patients, and in the sixth pigmentation had resolved after external irradiation, although plasma ACTH concentrations remained raised. All patients were receiving hydrocortisone replace- 
ment therapy and five were also on fludrocortisone; the doses remained constant throughout the study.

The study had a double blind crossover design. Plasma ACTH concentrations were determined on entry into the trial and at the end of periods on ketanserin (Janssen Pharmaceuticals) $40 \mathrm{mg}$ twice daily and placebo of at least two months each. At each assessment plasma ACTH concentrations were determined in three samples taken at half hourly intervals via an indwelling cannula at 0900 and 2400 on two successive days, and the results were expressed as the mean for each time of day. normal regulatory mechanisms by which the ACTH response to corticotrophin releasing factor is controlled and tonically inhibited by the circulating corticosteroid concentrations. ${ }^{3}$ The weight of experimental evidence favours a stimulatory role for serotonin in the regulation of ACTH secretion in normal man and it has been suggested that serotonin stimulates the release of corticotrophin releasing factor from the hypothalamus in the rat. ${ }^{4}$ Ketanserin is a quinazoline derivative which selectively blocks type 2 serotonin receptors. We have recently shown a

Plasma ACTH concentrations at 0900 and 2400 in five subjects with Nelson's syndrome on entry into the trial (basal values) and at the end of at least two months on ketanserin (40 mg twice daily) and placebo. Results are the mean (SEM) of a series of three samples taken at half hourly intervals on two successive days. Normal plasma ACTH at 0900 hours $=10-54 \mathrm{ng} / \mathrm{l}$

\begin{tabular}{|c|c|c|c|c|c|c|}
\hline \multirow{2}{*}{$\begin{array}{l}\begin{array}{l}\text { Case } \\
\text { No }\end{array} \\
1 \\
2 \\
3 \\
4 \\
5\end{array}$} & \multicolumn{2}{|c|}{ Basal values } & \multicolumn{2}{|c|}{ On ketanserin } & \multicolumn{2}{|c|}{ On placebo } \\
\hline & $\begin{array}{rr}91 & (8) \\
214 & (15) \\
794 & (100) \\
89 & (16) \\
252 & (7)\end{array}$ & $\begin{array}{ll}101 & (10) \\
735 & (55) \\
420 & (25) \\
108 & (26) \\
143 & (15)\end{array}$ & $\begin{array}{rr}56 & (6) \\
1340 & (72) \\
575 & (89) \\
209 & (31) \\
92 & (3)\end{array}$ & $\begin{array}{rr}80 & (10) \\
552 & (88) \\
393 & (45) \\
131 & (27) \\
104 & (2)\end{array}$ & $\begin{array}{rr}80 & (15) \\
1240 & (126) \\
830 & (82) \\
143 & (24) \\
102 & (15)\end{array}$ & $\begin{array}{rr}118 & (4) \\
509 & (57) \\
448 & (42) \\
209 & (7) \\
80 & (3)\end{array}$ \\
\hline Mean (SEM) & $288(131)$ & $275(109)$ & $454(240)$ & $276(114)$ & $479(236)$ & $272(87)$ \\
\hline
\end{tabular}

ACTH was measured in unextracted plasma by a double antibody radioimmunoassay using an anti-ACTH serum raised to synthetic (1-24) ACTH (IgG Corporation, Nashville, TN 37211, USA) and purified ACTH (Dr P J Lowry) for labelling and for standardisation (MRC $74 / 555$ assumed $11.6 \mu \mathrm{g} /$ ampoule). The detection limit of the assay was $10 \mathrm{ng} / \mathrm{l}$ and the interassay precision $8-12 \%$ (coefficient of variation) over the dose range studied. Results were analysed using Student's $t$ test for paired data.

\section{Results}

Basal ACTH values ranged from 89 to 794 and from 101 to $735 \mathrm{ng} / \mathrm{l}$ at 0900 and 2400 respectively. Ketanserin had no effect on plasma ACTH concentrations: the mean values (and standard error) at 0900 and 2400 were 454 (240) and 276 (114) ng/l respectively on ketanserin and 479 (236) and $272(87) \mathrm{ng} / \mathrm{l}$ on placebo (see table). Ketanserin was generally well tolerated but one subject discontinued treatment because of dizziness.

\section{Discussion}

The finding that patients with pituitary dependent Cushing's disease have an exaggerated cortisol response to corticotrophin releasing factor 41 suggests that there is impairment of the
$30 \%$ reduction in the $\mathrm{ACTH}$ response to hypoglycaemia after its intravenous use in normal man and therefore hoped to show a beneficial effect on ACTH levels in patients with Nelson's syndrome. ${ }^{5}$ Long term oral treatment with ketanserin did not, however, reduce the raised ACTH concentrations in these patients, and its further therapeutic use in Nelson's syndrome is not indicated.

This work was supported by the North of England Cancer Campaign and Wellcome Trust. We thank Janssen Pharmaceuticals for supplies of ketanserin.

\section{References}

' Dornhorst A, Jenkins JS, Lamberts SWJ, et al. The evaluation of sodium valproate in the treatment of Nelson's syndrome. F Clin Endocrinol Metab 1983;56:985-91. Aronin N, Krieger DT. Sustained remission of Nelson's syndrome after stopping

cyproheptadine treatment. N Engl f Med 1980;302:453-5.
3 Lytras N, Grossman A, Perry L, et al. Corticotrophin releasing factor: responses in normal subjects and patients with disorders of the hypothalamus and pituitary. Clin Endocrinol 1984;20:71-84.

4 Lewis DA, Sherman BM. Serotinergic stimulation of adrenocorticotrophin secretion in man. F Clin Endocrinol Metab 1984;58:458-62.

Prescott RWG, Kendall Taylor P, Weightman DR, Watson JM, Ratcliffe WA. The effect of ketanserin, a specific serotonin antagonist, on the PRL, GH, ACTH and cortisol resp

(Accepted 21 fune 1984)
The subject of the Medicine Stamp Tax is still being warmly discussed in many of the daily and weekly papers, and there is a general consensus of opinion that it should be abolished with as little delay as possible. In a remarkably able letter, signed "M.R.C.S.," which appeared in The Times of Monday last, it is pointed out that it is one of the chief causes of the excessive and unnatural infant mortality in this country. The system pursued is so well known to medical men that it is hardly necessary to refer to it in detail. When a child is born its parents obtain a "policy" upon its life from one or other of the various insurance-offices. A halfpenny, a penny, or twopence, arcording to the sum insured, is paid weekly to the collector when he makes his rounds. The policy is void if the child die within three months, but at any time after the expiration of that period the parents can obtain from 25 to 50 shillings on the production of the death-certificate. There can be no doubt that this abominable system is a direct premium on infanticide. It is fostered and maintained by the extraordinary facility with which poisons can be procured. Opiates disguised as "soothing syrup," "carminative," or "cordial," and even laudanum itself, are openly and freely sold in pennyworths by druggists all over the country. But various well known patent medicines afford a far more dangerous weapon, dangerous because its possession is without let or hindrance. The sale of patent medicines is, sad to say, totally unrestricted. While the poisonous drug is sold by qualified chemists and druggists only, the poisonous patent medicine can be sold by any huckster who chooses to pay a few shillings for a licence. Moreover, a careless use of a known poisonous drug involves serious legal responsibility, which does not apply to the use of a poisonous patent medicine. Because it bears the Government stamp it is unblushingly advertised as being "perfectly harmless." Mr. Daniel Grant, the member for Marylebone, speaking at the Westminster Hospital dinner on Wednesday last, referred to the existing state of affairs as a disgrace to a civilised country. He added that no subject demanded more earnestly the attention of Parliament, and expressed a hope that before long such an anomaly would be ranked with the things of the past. We most cordially endorse this opinion, and certainly think that active steps should be at once taken to obtain an amendment of the Act. (British Medical fournal 1884 ;ii :672.) 